\title{
Political economy of a euro area banking crisis
}

\section{By Panicos Demetriades}

\author{
Keynote Address at "Politics, Finance and Growth" Conference \\ Reserve Bank of South Africa, \\ Pretoria, 30 March 2016
}

\section{Introduction}

On Saturday, 16 March 2013, the world woke up to the news of an unprecedented levy on bank deposits that was to be applied in Cyprus, a euro area country, which was agreed as part of its long-awaited bail out agreement with Europe and the IMF. The levy was 9.99\% for deposits over $€ 100,000$ and $6.75 \%$ for deposits under $€ 100,000$. Given that deposits under $€ 100,000$ are protected by deposit insurance schemes throughout the European Union, the levy instantly raised questions concerning the safety of bank deposits in Europe and sent shock waves to bank depositors throughout the continent. ${ }^{1}$

What was even more surprising was that the deposit levy was to be applied to all banks in the country, not just those that faced capital shortfalls. It was intended to raise enough revenue to shore up the island's banking system and particularly for the recapitalization of the two largest lenders, Bank of Cyprus and Laiki, which had the biggest capital shortfalls. As such, it raised important questions relating to economic incentives, burden sharing and moral hazard. Why should insured depositors in healthy banks, for example, pay to bail out (uninsured) depositors in unhealthy banks? What are the implications for moral hazard if depositors who choose to invest in banks that are able to offer high deposit rates by taking excessive risks are bailed out by more cautious investors elsewhere? Why should small savers

\footnotetext{
${ }^{1}$ Depositors were particularly unsettled in countries in which banks were perceived as weak, such as Slovenia and Greece.
} 
pay to bailout wealthy investors in failing banks? What kind of precedent would such peculiar distortions set for future bank bailouts in Europe? ${ }^{2}$

The agreement was particularly shocking to Cypriot depositors, not least because the newly elected government of Nicos Anastasiades, which took office on 1 March 2013, had been reassuring the public that deposits in Cypriot banks were safe, dismissing reports in the international press which suggested that a haircut on bank deposits in Cyprus was imminent. Indeed, given the political cost of such a U-turn, the Cypriot government started distancing itself from the deposit levy soon after it was agreed, claiming that it had been blackmailed by the EGB, which allegedly threatened to cut off emergency liquidity assistance (ELA) to the Cypriot banking system if it did not agree to the levy.

Notwithstanding the numerous legitimate questions that were being raised nationally and internationally, in the early hours of the same morning the Central Bank of Cyprus instructed all banks on the island to shut down their electronic payments systems to prevent deposit flight. Banks were to remain closed until parliament voted on the levy, although parliamentary approval looked highly uncertain from the outset. ${ }^{3}$ It wasn't just that the government did not have a majority in parliament and that opposition parties were quick to indicate that they would not support such an unpopular levy. It was also that the ruling political party itself showed no enthusiasm for the levy and, like the government, distanced itself from it. When it came to voting, the ruling party instructed its MPs to abstain from the vote, arguing that the Eurogroup had made a mistake that needed to be rectified.

The on goings of the Cypriot domestic political scene did not go unnoticed. This was after all Cyprus' moment in international financial history: the parliament's vote could make or break the euro. Without approval of the levy, the future of both Cyprus and the euro was in jeopardy. Without the ECB's support, the banks would remain closed indefinitely, unless if they could be reopened under a new currency regime. Euro liquidity would soon dry up given the loss of depositor confidence, reflected in long queues at ATMs. Without banks, the economy would be paralyzed. This would, of course, have brought added pressure on the

\footnotetext{
${ }^{2}$ An article by Bloomberg quotes the chief international economist at Morgan Stanley in London saying that the [deposit] tax is "a worrying precedent with potentially systemic consequences if depositors in other periphery countries fear a similar treatment in the future". See: "Euro Officials Signal Flexibility in Cypriot Bank Levy", by P. Donahue and M. Bensasson, 18 March 2013. http://www.bloomberg.com/news/articles/2013-0317 /europe-braces-for-renewed-turmoil-as-cyprus-deposit-levy-at-risk

3 The central bank was never consulted about the levy. When the governor's opinion was requested by parliament, he argued against taxing insured deposits because of the effects on depositor confidence. He explained that the same revenue could be raised with a slightly higher tax $(16.5 \%)$ on uninsured deposits. In response to this, the Cypriot ministry of finance altered the initial proposal by excluding the first $€ 20000$ from the levy but did not explain how the shortfall would be raised.
} 
government for an agreement but it could also have resulted in a political backlash, pushing parliament to reject the 'blackmail' and vote to exit the euro.

On Monday, 18 March 2013, when financial markets around the world reopened, there was a noticeable reaction to the news of the deposit levy in Cyprus. ${ }^{4}$ The uncertainty that had been created raised questions about the euro's survival. Without an agreement in Cyprus, the euro could begin unravelling. Not surprisingly, perhaps, the world's media turned their attention to the island.

On 19 March, the Cypriot parliament, predictably, voted down the deposit levy. Two days later, the ECB made an unprecedented public announcement that it would cut off liquidity from Cypriot banks unless a new agreement between the Eurogroup and the Cypriot government, which ensured that banks were adequately capitalised, was reached by 25 March. The ECB's decision, and particularly its decision to make it public - a first for an ELA decision - was controversial. However, it helped to focus minds within the Cypriot government and the wider political landscape. This was not a bluff. The message was loud and clear: without an agreement, there would be a disorderly default of the sovereign. The banks could not reopen without introducing a new currency. Exit from the euro area, if not the European Union, was almost inevitable. For a country that joined the EU in 2004, partly in order to protect its sovereignty, this could have turned into a national catastrophe.

In the early hours of Monday, 25 March 2013, a new agreement was reached between the Eurogroup and the Cypriot government, which prevented the breakdown of the euro and protected Cyprus from a disorderly default. This agreement did away with the unpopular and universal deposit levy but involved bailing in (imposing large losses on) depositors and other creditors of the troubled banks. ${ }^{5}$ On the same day, the Central Bank of Cyprus embarked on an unprecedented programme of resolution and restructuring of the national banking system, as part of the EU/IMF adjustment programme, the details of which were to

\footnotetext{
${ }^{4}$ For example, the Guardian reported heavy losses in Asia, smaller losses in Europe and a fall on Wall Street by 60 points, all attributed to the news of the deposit levy in Cyprus. See: http://www.theguardian.com/business/2013/mar/18/eurozone-crisis-cyprus-bailout-savers-markets.

Bloomberg provides a more comprehensive analysis of the reaction in financial markets on the same day, which also included a weakening of the euro and a rise in Italian and Spanish bond yield. See:

http://www.bloomberg.com/news/articles/2013-03-17/europe-braces-for-renewed-turmoil-as-cyprus-depositlevy-at-risk
}

\footnotetext{
${ }^{5}$ As such, it helped to evade the questions relating to economic incentives and regressive nature of the universal deposit levy, although the question of why such a distortionary tax was acceptable to Euro area finance ministers in the first place will probably remain unanswered.
} 
be agreed in the weeks that followed. Capital controls were introduced to protect the fragile deposit base, another first for the European Union.

Three years on, the economic adjustment programme for Cyprus was completed at the end of March 2016 and is widely considered successful in terms of restoring the sustainability of public finances, returning the banking system to stability and the economy to positive growth rates. ${ }^{6}$ However, the longer-term implications of bailing in depositors remain unclear.

This paper contributes to a growing literature on banking crises by providing insights into one of the costliest systemic banking crises in modern financial history. Laeven and Valencia's (2013) analysis of 147 banking crises since 1970, all of which predate the Cypriot crisis, pinpoints Indonesia 1997 as the costliest crisis in terms of fiscal costs. The fiscal cost of the Indonesian crisis was 57\% of GDP. In March 2013, Cyprus faced a potential fiscal cost of approximately $59 \%$ of its GDP to bailout its banks. ${ }^{7}$ Additionally, the paper contributes to various strands of the finance-growth literature by: (a) adding to the growing skepticism relating to the ability of finance to promote economic growth once a certain threshold of financial development has been achieved (e.g. Arcand et al 2015); and (b) providing further credence to the conclusions in Andrianova et al (2012) that corrupt politicians in democracies may find it easier to extract rents from poorly regulated private banks than from governmentowned ones.

The paper is structured as follows. Section 2 provides an overview of the main ingredients of the crisis, while Section 3 provides its timeline. Section 4 analyses the deeper political economy origins of the crisis while Section 5 discusses the management of the crisis. Section 6 outlines some unintended consequences of the resolution measures which were adopted, highlighting the erosion of central bank independence as one of their significant negatives. Section 7 summarises and concludes.

\section{Ingredients of the crisis}

Cyprus joined the European Union in 2004 and the euro in 2008. During 2005-2011, the Cypriot banking system's assets more than doubled in size, increasing from €69.1 billion to $€ 141.2$ billion. Relative to the economy, total banking sector assets peaked at $953 \%$ of

\footnotetext{
${ }^{6}$ Capital controls were lifted in 2015 and the economy returned to growth. The remarkably quick recovery is highlighted in Balazs (2016).

7 Although the taxpayer was eventually spared about two thirds of this cost, the losses were shifted to private creditors through the use of the bail-in tool.
} 
GDP in 2010 while domestic banks' assets, which are more representative of the contingent liability for the national taxpayer, peaked at over six times GDP, the highest in the EU. ${ }^{8}$

A large banking system, even if it does not get itself into trouble, represents a substantial contingent liability for the taxpayer. Depending on the extent of support required, bailing out a large banking system could involve a very significant burden for the taxpayer, which can push public debt to unsustainable levels. ${ }^{9}$ This turned out to be the case in Cyprus, not just because of the large size of domestic banking sector assets relative to GDP but also because of the excessive risks that the island's two largest lenders took and the lax lending standards prevailing throughout the sector (including the cooperative credit sector which represented the third largest banking group on the island). ${ }^{10}$

Between them, the two largest lenders accounted for nearly two thirds of domestic banking sector assets: their combined assets were about four times GDP. The risks they took were extraordinarily large, not least because of their exposure to Greece through their extensive branch network, which accounted for nearly 140\% of Cyprus' GDP. With the Greek economy being in a deep and protracted recession since 2009, the quality of their assets was deteriorating rapidly due to rising non-performing loans (NPLs). As if that was not enough exposure to the riskiest country in Europe, the two lenders chose to invest in high risk, high yield bonds issued by the Greek government (GGBs). The amounts involved were staggering: between them the two banks invested amounts equivalent to almost their entire capital or about one third of the country's GDP, in GGBs. Such risk concentration, by itself, highlights important deficiencies in risk management systems and corporate governance; it also raises questions relating to regulatory processes and banking supervision. ${ }^{11}$ These excessive and highly concentrated risks crystallized in 2011 when the Greek PSI (debt write-

\footnotetext{
${ }^{8}$ For an excellent analysis of the banking system in Cyprus and the risks it represented before the crisis, see Stephanou (2011a, 201 lb). For a more detailed overview of the Cypriot banking system after the crisis, including some excellent insights into the causes of the crisis, see Lascelles (2013).

9 The experience of Ireland was perhaps even more striking as the Irish bank bailout resulted in public debt increasing by $73 \%$ of GDP (Laeven and Valencia, 2013).

${ }^{10}$ Prior to the crisis there were 86 regional credit cooperatives.

${ }^{11}$ Under the then prevailing regulatory regime of Basel II, excessive risk concentration was normally addressed under Pillar II, by the banks via their ICAAP (internal capital adequacy assessment process) and by the Regulator via SREP (supervisory review and evaluation process).
} 
down $)^{12}$ was agreed, as a result of which the two Cypriot banks suffered losses of around 80\% of these bond holdings that nearly wiped out their entire capital base. ${ }^{13}$

The banking system's growth in liabilities owed a lot to close economic and banking ties with Russia, which resulted in substantial capital inflows, largely through increased numbers of Russian companies registered in Cyprus. Not surprisingly, capital inflows helped to create a credit boom and an unsustainable property bubble. By December 2011, private sector indebtedness had reached $286 \%$ of GDP and was the third highest in the European Union. By contrast, in December 2011, public debt in Cyprus was 71\% of GDP, which was the 11th highest in the EU. It is, therefore, obvious that the Cypriot crisis had primarily banking origins, although the state of public finances and its trajectory was also a contributory factor in that it provided very limited, if any, fiscal space to bail out the banks. Indeed, all the rating downgrades that occurred in the months prior to the crisis pointed to the large contingent liability that the Cypriot banking system represented for public finances, especially in light of its exposure to Greece. By and large, these downgrades followed closely the deterioration of the Greek economy and led to Cyprus losing access to international financial markets in the summer of 2011. Nonetheless, the Cypriot government remained afloat through a bilateral $€ 2.5$ billion loan from Russia that was agreed at the end of 2011.

The links between Cypriot banks and Russia represented another important dimension of the crisis and its eventual resolution, since they had created the perception, particularly in Germany but also elsewhere in Europe, that the Cypriot banking system was not clean. In the latter part of 2012, when Cyprus' request for financial assistance began to appear on Eurogroup's agenda, German media started running stories describing Cyprus as a money laundering heaven for rich Russians. While the evidence supporting such allegations was, at best, questionable - for example, Moneyval had rated Cyprus' anti money laundering (AML) regime as being of a higher standard than that of many other European countries including Germany's ${ }^{14}$ - this did not prevent the media and indeed opposition parties in Germany from raising the question of why the German taxpayer should be helping to bailout wealthy

12 For a detailed analysis of the Greek PSI see Zettelmeyer, Trebesch and Gulati (2013).

13 Although the Cypriot government was widely blamed for agreeing to the Greek PSI, the issue begs the question of why banks tolerated such an excessive concentration of risk at a time when the possibility of Greek debt restructuring was being openly debated. Moreover, the then Christofias government itself pointed to assurances given publicly by the then central bank governor (Athansios Orphanides) that the banks could withstand a Greek debt restructuring. This is a highly contentious issue, especially in light of the widely reported poor relations between Christofias and Orphanides.

14 See, for example, P. Demetriades "Cyprus: not blameless but misunderstood", The Financial Times, 22 January 2013. 
Russians in Cyprus. As Germany was entering a pre-election period towards the end of 2012 and beginning of 2013, these views appeared, with the benefit of hindsight, to have been critical in shaping the conditionality that would eventually be attached to the bailout. Leaks in the European press in February 2013 did, in fact, suggest that a bail-in of uninsured deposits was among the options that were being discussed, because it would protect public finances and impose losses on foreign investors, especially from Russia. ${ }^{15}$ Not surprisingly, such leaks destabilized the Cypriot banking system further, causing massive deposit withdrawals and resulting in increased reliance on ELA. They also spilled over into the Cypriot pre-election debate, turning the perceived credibility of assurances made by presidential candidates that a deposit haircut would not be acceptable, as well as the strength of presidential candidate's relations with Europe, into significant factors that influenced voting intentions. ${ }^{16}$ The incoming president was, therefore, faced with reneging on his pledge to the electorate or abandoning the euro in his first few days in office.

\section{How the crisis unfolded ${ }^{17}$}

The stress tests conducted by the European Banking Authority in 2011 revealed significant shortfalls for both Laiki and Bank of Cyprus. ${ }^{18}$ In line with all the other banks in Europe that experienced capital shortfalls, the Cypriot lenders were given until 30 June 2012 to raise capital privately. Prior to that, EU governments had agreed to provide a backstop to banks that did not succeed in raising capital privately, in order to safeguard financial stability. In the first few months of 2012, the local press was full of stories that suggested that the two banks would be able to cover their capital shortfalls. At the start of 2012, the Central Bank forced a change in Laiki's top management, which was intended to help this effort. However, Laiki requested state aid within a few days of the change of Central Bank governor, which took place on 3 May 2012. About six weeks later, Bank of Cyprus followed suit, only days after its AGM re-elected its board and chairman and just before the EBA deadline was about to expire on 30 June 2012.

\footnotetext{
${ }^{15}$ See, for example, P. Spiegel and Q. Peel "Radical rescue proposed for Cyprus", The Financial Times, 10 February 2013.

16 Shortly before the election, the European Popular Party held a meeting in Cyprus during which German Chancellor Angela Merkel demonstrated publicly her support for one of the presidential candidates (Nicos Anastasiades).

17 The information in this section draws on a variety of publicly available documents, including Central Bank of Cyprus (2013a, 2013b), Demetriades (2013) and various interviews by the central bank governor during 201213.

${ }^{18}$ Details of the tests and results can be found on the EBA website: http://www.eba.europa.eu/risk-analysisand-data/eu-wide-stress-testing/2011/results.
} 
With the two largest banks requiring a bailout, which in all likelihood would have been of the order of several billion euros and the Cypriot government having no access to international financial markets, the government tried, once again, to secure another bilateral loan from Russia but did not succeed. It was, therefore, forced to apply for an unpopular EU/IMF bailout that would enable it to recapitalise the banking system and restore its public finances. Technical teams from the IMF, the European Commission and the ECB (the 'troika') visited the island in July 2012 and submitted programme proposals to the government during the same month. As part of the negotiations, it was also agreed that an independent consultant be appointed to carry out a diagnostic exercise to determine the capital needs of systemic banks, including the credit cooperative sector. ${ }^{19}$

However, the left-leaning government of Demetris Christofias objected to the proposed labour reforms, privatisation of state enterprises and cuts to social spending. It undertook to submit counter-proposals to the 'troika' but took its time to do so. A new round of negotiations began in the late autumn of 2012 but negotiations came close to collapsing in November 2012, over the details of labour reforms.

With the political heat between the government and the opposition reaching unprecedented levels, news of a confidential ECB Governing Council decision to impose a deadline on emergency liquidity assistance to Cypriot banks was leaked to the Cypriot media. Depositors were becoming increasingly nervous and on 21 November 2012 Laiki faced a run on deposits. The bank run proved catalytic. It helped to convince the government that the stability of the banking system, which was at stake, was perhaps more critical than maintaining a principled stance on labour reforms. Within hours, President Christofias announced that the government was close to agreeing all the details of an adjustment programme with the troika. The bank run quickly died down even before the troika had confirmed that this was indeed the case. That agreement with the troika included a provisional sum of $€ 10.0$ billion to recapitalise the banking system, which, as a percentage of GDP, would have made it one of the costliest banking crises in the world as a percentage of GDP, with a fiscal cost of about $57 \%$ of GDP. ${ }^{20}$

\footnotetext{
19 The process was managed by a steering committee with representatives from the European Commission, the European Central Bank, the IMF, the European Banking Authority, the European Stability Mechanism and the Cypriot authorities (central bank, ministry of finance and the regulator of the credit cooperative sector). ${ }^{20}$ In their excellent analysis of systemic banking crises around the world, Laeven and Valencia (2013) show that
only Indonesia 1997 had a similar fiscal cost.
} 
However, that preliminary - as it turned out - agreement was not the end of the crisis. The Eurogroup was no longer prepared to endorse the agreement with the troika. The reason given was that the diagnostic exercise relating to the precise capital needs of the banking system, which was being carried out by an independent specialist firm, would not be finalised until January 2013. Moreover, by January 2013 the Cypriot presidential elections were looming; opinion polls were showing Nicos Anastasiades, a centre-right candidate who campaigned on his pro-bail out, pro-European credentials as the likely winner. The Eurogroup announced on 21 January 2013 that it had decided to wait for the elections to 'best facilitate national ownership' of the programme. ${ }^{21}$

The elections did indeed return Nicos Anastasiades to the presidency on 1 March 2013. The new minister of finance, Michael Sarris, attended his first Eurogroup meeting on 4 March 2013. At that meeting, Sarris was informed that the IMF's Debt Sustainability Analysis (DSA) showed that the government could only afford to bailout the credit cooperatives (which needed a capital injection of $€ 1.5$ billion - approximately $9 \%$ of GDP) but could not afford to bail out the two big banks. The island's two largest lenders were simply too big to save ${ }^{22}$. As a result, the minister was informed that there had to be a very substantial contribution from depositors amounting to $€ 5.8$ billion. The government of Cyprus was invited to come up with its own proposals, although it appears that the IMF had made clear that its own preference was to resolve the two troubled banks and to bail in uninsured depositors. A new Eurogroup meeting was called for 15 March 2013, following on from an EU Council meeting. This was to ensure that President Anastasiades attended so that whatever was agreed would have endorsement by the highest level of the Cypriot government. According to statements by the German government and the German embassy in Nicosia, the universal deposit levy was the Cypriot government's preferred way to raise the required contribution from depositors. Although the Cypriot government rejected these claims, both President Anastasiades and the then minister of finance, Michael Sarris, subsequently argued - on several occasions - that the universal levy would have spread the burden more broadly and therefore more fairly. ${ }^{23} 24$ Another important factor was that the

\footnotetext{
21 The Eurogroup announcement also called for the final agreement to 'provide for a close monitoring of the Anti-Money Laundering and tax transparency frameworks and their implementation'.

22 The information in this section is publicly available from the central bank governor's interviews with various media during 2013 and 2014.

${ }^{23}$ On this (and related issues) see the documents submitted by the government to the Judicial Inquiry on the crisis (in Greek), available from: http://www.philenews.com/el-gr/top-stories/885/159075/i-dilosi-anastasiadimeta-tin-katathesi-stin-erevnitiki-epitropi.
} 
broad-based deposit levy was perceived as less detrimental to the 'Cypriot business model', which involved attracting Russian capital flows to the island, as it would have minimized the loss to uninsured foreign depositors. ${ }^{25}$

After the deposit levy was turned down by the Cypriot parliament on 19 March 2013, the Cypriot government sent its finance minister to Moscow to plea for a new bilateral loan. The view among all parliamentary political parties in Cyprus was that Europe and the IMF had been grossly unfair, wishing to impose a haircut on deposits that was never used anywhere else. Not surprisingly, perhaps, Sarris was unsuccessful and resigned from office a few days after his return to Cyprus. ${ }^{26}$

Soon after the ECB announced its ELA decision on 21 March 2013, queues at ATMs became even longer. Laiki's cash buffers were getting thinner and thinner. If the bank was unable to meet depositor withdrawals, it could become technically insolvent. That could trigger claims by insured depositors for compensation. The Republic's deposit insurance fund amounted to about $€ 130$ million. Insured deposits in Laiki alone were over $€ 4.0$ billion. If Laiki had ran out of cash, a series of default events could be triggered and it was not obvious what would happen next. The country was facing a disorderly default of its main banks, a disorderly default of the sovereign, euro exit, as well as financial and economic meltdown.

At the same time, some members of the political establishment, particularly those who had been supportive of the bankers, were looking for a scapegoat. Because the ECB was seen as the source of the 'blackmail', the provision of emergency liquidity assistance by the central bank - an important safeguard for the stability of the banking system - came under attack. With the help of sections of the media, it was conveniently portrayed as the primary cause of the crisis. This was perhaps the first ever time in financial history that liquidity support to the banking system by a central bank was demonized. Moreover, conspiracy theories involving

\footnotetext{
${ }^{24}$ In a recent interview, Michael Sarris claimed that parliament has a major responsibility for voting down the universal deposit levy and goes on to argue that bailing in uninsured depositors in the troubled banks was a much harsher decision. See:

http://www.stockwatch.com.cy/nqcontent.cfm?a_name=news_view\&ann_id=253368

25 See Section 4 for more details on the 'business model'.

26 The Russian government, in fact, indicated that it was only willing to consider further financial assistance to Cyprus if the country embarked on an EU/IMF program that would restore the sustainability of its public finances.
} 
foreign countries that wanted to 'destroy our banking system' started circulating in the media, suggesting that the capital needs of the banking system had been deliberately exaggerated. ${ }^{27}$

At that point, the top priority of the central bank was not to respond to criticism but to help prevent financial and economic meltdown. To this end, the central bank, took a number of initiatives that helped convince the government and parliament to enact much needed resolution legislation on 22 March 2013. The resolution bill was the outcome of months of work at the technical level by the central bank and the ministry of finance, in close collaboration with the European Commission, the EGB and the IMF. The law provided the central bank with the necessary modern resolution tools. The 'bail in' tool, which proved highly controversial, was a last minute addition to the legislation when prospects of a full bailout began to fade. Even then, its use was not automatic, requiring political consent (in the form of the finance minister's approval) before a bank was brought under resolution. In light of the political agreement that was eventually reached, the legislation, including the bail-in tool, was necessary to implement the Eurogroup's decisions relating to the resolution and restructuring of the two banks without the use of taxpayer funds. Agreement between the Eurogroup and the Cypriot government was, of course, the starting point for the process of resolution and restructuring to begin as it enabled the ECB to continue to provide vital liquidity support to the banking system. The agreement was also vital in preventing a disorderly default of the sovereign, as the government's cash buffers had nearly been exhausted.

A preliminary agreement between the troika and the Cypriot government was reached in the late hours of Saturday, 23 March 2013, following intense negotiations. ${ }^{28}$ The agreement involved resolution and restructuring of the two banks using the bail-in tool to cover the capital shortfall, which would help put the public finances on a sustainable path. An emergency meeting of the Eurogroup in Brussels was called for the following night of Sunday, 24 March, which endorsed that agreement in the early hours of Monday 25 March. The process of restructuring and resolution started shortly after the Eurogroup's decision was publicly announced, with the signing of decrees bringing both banks under resolution by the Minister of Finance and the Central Bank Governor.

\footnotetext{
27 During the presidential pre-election campaign candidates criticised the methodology of bank stress tests, which supposedly inflated the capital needs of the banks. It turned out that even after the banks were fully recapitalised using the adverse scenarios of the diagnostic exercise, a fresh capital injection was needed to pass the ECB stress tests conducted in the fall of 2014.

${ }^{28}$ By that time it became clear that the Russian Deus-ex-machina would not materialise and that the only viable option was to resolve the troubled lenders, and confine the bail in to their uninsured depositors.
} 


\section{Origins of the crisis}

The seeds of any banking crisis are nearly always found in the preceding boom. Cyprus was no exception. The euphoria that followed joining the EU in 2004 was in large part responsible for risks being under-estimated, very much in line with the financial instability hypothesis put forward by Minsky (1992). It was also largely responsible for the influx of foreign capital into the country's banks and the property market. Limassol, on the island's south coast, attracted thousands of foreign companies and became a base for business and second homes for many wealthy Russians.

Capital inflows were not spontaneous. They owed a lot to the Cyprus business model, the origins of which can be found in the island's transformation in the late 1970s and 1980s into an 'offshore' business centre. At that time, Cyprus marketed itself as a more stable regional alternative to Lebanon, which had been the region's business hub until it became embroiled in civil war. In the 1990s, Cyprus' offshore status, common law legal system and geography proved an attraction to new Russian and Ukrainian entrepreneurs aiming to avoid high domestic taxes or corrupt courts to settle business disputes. Although Cyprus lost its 'offshore' status when it joined the EU in 2004, Russian and Ukrainian company registrations remained buoyant as Cyprus opted for the lowest corporate tax rate in Europe $(10 \%)$. Moreover by the early 2000s, Cyprus already possessed a large and successful industry of law and accounting professionals who were quick to exploit the opportunities offered by postcommunist Russia and other countries of the former USSR. Cypriot law and accounting firms helped these entrepreneurs set up thousands of companies in Cyprus and acted on their behalf in numerous legal disputes. ${ }^{29}$ They also facilitated the opening of bank accounts in the country's banks, which had geared themselves up for attracting the business of wealthy foreign clients by setting up international business divisions. ${ }^{30}$

The business model had important political economy dimensions, which revolved around politically connected law firms and the wider interest group of professional services, including accountancy firms, other law firms and banks.

Politically connected law firms acted as catalysts for Russian business and capital inflows. Mixing law, politics and business had always been common practice in Cyprus. Members of parliament who were not practicing lawyers were an exception rather than the

\footnotetext{
${ }^{29}$ Deakin (2016) analyses the weakness of the Russian legal system, which explain why Cyprus law often acts as a substitute because of its common law characteristics and fair courts.

30 For more details on the Cyprus business model see Lascelles (2013) or Stephanou (2011b).
} 
norm. The practice of law was not limited to politicians elected to parliament. It was also quite common at the highest levels of government. Indeed, four out of seven presidents since Cyprus gained its independence from Britain in 1960 have been lawyers, whose family law firms continued to operate during their terms of office, although they were officially run by partners or relatives.

Politicians did not refrain from exercising influence over the affairs of banks. This happened through control of the central bank board, which was the bank's supervisor, or through control of commercial bank boards or the committees of credit co-operatives.

Before Cyprus joined the EU, the central bank had limited, if any independence, from the government, as the government could exercise a veto on central bank decisions through its representative on the central bank's board of directors. Moreover, the president had the constitutional right to dismiss the central bank governor at will. Given the central bank's role as supervisor of the banking system, this translated into near complete control over the affairs of banks, including, for example, the authority to approve changes in bank ownership, fitness and probity checks for bank directors and issuing directives that governed lending and corporate governance within banks.

When Cyprus became a member of the European Union in 2004, the constitution was amended to protect the independence of the central bank. The government lost the right of automatically dismissing the central bank governor at will. It also lost its veto power on the central bank's board. Old habits, however, die hard. Politicians continued to try to exercise influence over central bank decisions using their influence over board members, whose independence is not protected by law, and by exerting indirect pressure on central bank governors through the use of their influence over the media, parliament and the legal system, arguing that the governor's independence is limited to matters of euro area monetary policy.

In 2005-06, soon after Cyprus joined the EU, there was a change of ownership in Laiki, which is now widely considered to have been at the root of the bank's demise. Up to that point, the bank's largest shareholder was HSBC with a share of 20\%. HSBC expressed an interest in acquiring majority ownership, which was rejected by the central bank. While the rationale behind that regulatory decision remains unclear ${ }^{31}$, its consequences are undisputed: that decision forced HSBC to sell its stake in Laiki and enabled a Greek tycoon to acquire control of the bank by buying shares through an opaque transaction that allegedly

\footnotetext{
31 Press reports suggest that there was political interference by the then President of the Republic whose law firm was the external counsel for Laiki bank.
} 
circumvented the process of regulatory approval that would normally be required. What followed was years of connected lending and alleged looting that is now the subject of a major criminal investigation by the Cypriot police.

Cypriot lawyer-politicians had a clear advantage over other lawyers in attracting Russian business. In post-communist Russia, success in business without political connections or political backing is challenging, if not altogether impossible. In Cyprus, many lawyerpoliticians had direct links with banks. Some of these links allegedly involved banks paying lawyers lucrative commissions for introducing wealthy Russian depositors (known as 'introducer fees').

The links between banks and lawyer-politicians helped to ensure that banks avoided close scrutiny when they began to take on excessive risks. ${ }^{32}$ As the central bank was accountable to parliament for its banking supervision function, parliament had every right and every obligation to exercise parliamentary scrutiny. Although the rating agencies made it abundantly clear that the banks represented a growing contingent liability for the country's public finances, during 2007-12 parliament refrained from asking the central bank penetrating questions relating to how these risks were being managed. Instead, the opposition parties that represented a majority in parliament during the Christofias period deflected attention from the banks by focusing discussions in parliament on the deterioration in public finances and increases in social spending. The media, which depended on the banks for advertising, adopted the same stance. So much so, that critical articles about banks' risk taking were censored. ${ }^{33}$ By the time parliament woke up to the enormous contingent liability that had been created by the banking system, it was far too late to do anything. ${ }^{34}$

Failures in risk management within the two big banks were pretty obvious to independent observers, as was the failure of the central bank to tighten regulation to prevent excessive risk taking by the banks in the years prior to the crisis. ${ }^{35}$ However, these weaknesses conveniently escaped the attention of much of the media, which was largely captured by the banks, for the reasons already alluded to above.

\footnotetext{
32 The same links, as well as the desire to protect the business model, also provides a political economy rationale for the universal deposit levy which was proposed by the newly elected government, which was closely associated to the bank-lawyer-accountant interest group.

${ }^{33}$ Evidence was presented in a recent court case by M. Olympios, Chairman of the Cypriot Investor's Association, whose column in the independent newspaper Politis was cancelled because it was critical of Bank of Cyprus. The bank threatened the newspaper with reduced advertising expenditure. The case involves criminal charges against the Bank of Cyprus concerning market manipulation.

34 For greater analysis of how the risks were ignored see Lascelles et al (2013).

35 See, for example, Lascelles (2013). These failures are also documented in Demetriades (2012).
} 
In both banks corporate governance was lax, as were lending standards and the definition of non-performing loans. ${ }^{36}$ Credit was granted not on the ability to repay but on the basis of collateral availability. Loans that were 90 days overdue were not classed as nonperforming if, in the bank's judgement, they were adequately collateralised. There were no limits for lending to individual bank directors and there were only two independent directors on bank boards. In the case of the Bank of Cyprus, a real estate developer who had the backing of the bank's largest shareholder was elected as Chairman. During his term of office, connected lending to his companies increased by several hundred million euros, most of which quickly became non-performing. Not surprisingly, the chairman's oversight over the excessive risks taken by the bank's CEO was rather lax. The bank chose to invest an amount equal to about $100 \%$ of its equity capital in Greek Government Bonds, after the onset of the Greek crisis. Arguably, this was a gamble for resurrection as its income from its loan portfolio had fallen sharply due to rising NPLs. Other examples of excessive risk taking involved acquiring majority stakes in retail banks in countries in which the Cypriot banks had little experience of operating in, such as Russia, Ukraine and Romania.

The main lesson to be learnt from the above analysis is that media, political and regulatory capture can help explain why large, privately-owned banks can be particularly challenging to regulate. Indeed, the experience of Cyprus provides a good justification for the establishment of the Single Supervisory Mechanism (SSM) in Europe. Discussions about the SSM started at the same time as the onset of the Cypriot crisis in the summer of 2012 and were, of course, also informed by previous crises in Ireland, Spain, Portugal and Greece. One of the key advantages of the SSM is that it breaks the link between national regulators and national banking systems. A secondary conclusion is that rapid financial development that results in a large banking system entails very large risks; if these risks are not well managed it is unlikely to promote growth. These conclusions are very much in line with the literature that warns against wholesale acceptance of the view that finance is always good for growth (e.g. Arcand et al, 2015; Demetriades and Rousseau, 2015; Demetriades and Hussein, 1996).

\section{Resolution and restructuring}

The agreement of 25 March 2013 between the Cypriot government and the Eurogroup included the sale of the Cypriot bank branches in Greece, as a prior action. The rationale

\footnotetext{
36 There were similar governance and regulatory failures in credit cooperatives, although the risks in the cooperative sector were confined to Cyprus.
} 
behind this decision was to reduce contagion between the two countries, which could have destabilised the Greek banking system just as it was beginning to show signs of stability. ${ }^{37}$ Looking ahead, however, it was also likely to prove highly beneficial for Cyprus since it helped to ring-fence the Cypriot banking system from the risk of Grexit, which could have resurfaced later, as indeed it did towards the end of 2014 and the first half of 2015 (because of the change of government in Greece and the political uncertainty surrounding the political process and new negotiations). Cyprus, however, was hardly affected because its banking system had already been ring fenced.

The Greek carve-out was effected within days. The buyer of the Cypriot bank branches in Greece was selected by the Hellenic Financial Stability Fund, which held a bidding process to that effect. The terms of the sale had been agreed by the Eurogroup, following agreement at a technical level between the Greek and Cypriot troikas. The details of the agreement nevertheless took several days of negotiations that involved numerous legal teams, representing various parties involved.

Meanwhile, both Laiki and Bank of Cyprus were brought under resolution by the central bank with the consent of the ministry of finance, in order to implement the resolution and restructuring measures that were agreed at Eurogroup on 25 March. These included splitting Laiki into a 'good' bank that was to be absorbed by Bank of Cyprus and a 'bad' (or legacy) bank, which was to be liquidated. All Cypriot-booked assets of Laiki, including NPLs, went into 'good' Laiki, the liabilities of which included all insured deposits and all central bank borrowing. The remaining assets of Laiki, which included subsidiaries abroad and a stake in the new Bank of Cyprus, remained in the legacy bank, which, by definition, was insolvent and, therefore, eventually lost its banking license. Uninsured depositors and other creditors remained in the legacy bank, to be compensated when the assets of that bank are liquidated. Bank of Cyprus was recapitalised through a conversion of uninsured deposits into equity (bail in). The bail in was finalised at the end of July 2013, once a fair valuation of the assets and liabilities of Bank of Cyprus and 'good' Laiki had been carried out. In total, 47.5\% of the value of uninsured deposits were converted into equity, providing a Core Tier 1 capital ratio of over $12.0 \%$. As a result, the bank was taken out of resolution and regained its

\footnotetext{
37 A collapse of the Cypriot banking system would have necessitated closing down the branches of Cypriot banks in Greece, which represented about $11 \%$ of banking system assets in Greece. If the branches remained in Cypriot hands, losses would have had to be imposed on Greek depositors, which could have triggered a more widespread bank run in Greece.
} 
monetary policy counterparty status with the ECB at the beginning of August 2013, and embarked on a long journey of returning to normality.

Additional restructuring and recapitalisation measures were taken in relation to the credit cooperative sector, which aimed at restoring the sector's viability and resilience. Over 80 local cooperatives, some of which were too small to be viable as stand-alone entities, were merged into 18 regional credit cooperatives under the umbrella of the Central Cooperative Bank, which acquired new management powers over the regional entities. Furthermore, responsibility for regulating and supervising credit cooperatives was transferred from the Ministry of Commerce to the Central Bank of Cyprus. The capital injection into the cooperative sector amounted to $€ 1.5$ billion of programme funds out of the $€ 2.5$ billion earmarked for bank recapitalisation under the country's adjustment programme.

\section{Political and economic fallout}

Although the bail in protected the public finances by reducing the banking sector bail out bill from initial estimates of $€ 10.0$ billion to €2.5 billion, it affected the wealthiest and arguably the most influential individuals and institutions, many of whom were quick to protest. The fallout from the bail in included unprecedented political and media attacks on the central bank, which was the institution that took the resolution actions. It also included numerous challenges in courts of law. ${ }^{38}$

Soon after the resolution measures were announced, hundreds of employees of Bank of Cyprus demonstrated outside the central bank, demanding the governor's resignation. The view from within the bank's senior management and board, which was propagated through local media and politicians, was that Bank of Cyprus was a healthy bank that had been unfairly treated. The methodology of the diagnostic exercise that revealed the capital shortfalls was questioned. Populist conspiracy theories involving communist plots, the governor and foreign powers who wanted to destroy the Cypriot economy emerged and were even voiced in parliament. Such conspiracy theories resonated well among bank shareholders, bondholders and uninsured depositors, whose wealth was eroded by the resolution measures. The largest shareholder of Bank of Cyprus (the Greek Orthodox Church), obtained a court injunction to freeze the provision of the decree involving writing

\footnotetext{
38 None of the legal challenges against resolution actions taken by the central bank have to date been successful. In fact, the Supreme Court upheld the constitutionality of all resolution actions and referred applicants too district courts where they need to demonstrate that they would have been better off if banks had been liquidated. The basic principle of resolution legislation is that resolution helps protect value vis-à-vis liquidation: no one should be made worse off by resolution compared to liquidation.
} 
down its shares. In addition, the Head of the Church used his privileged position (including interviews after Sunday service) to launch personal attacks against the governor through television and other media. ${ }^{39}$

Political interference during this period escalated, notwithstanding the watchful eye of the troika. ${ }^{40}$ The political attacks in parliament during March 2013, which included demands for the governor's resignation, were followed in April 2013 with the dismissal of the deputy governor, who had been appointed by the previous government only a few months earlier. ${ }^{41}$ The campaign continued with regular attacks on the central bank and its governor through the media for alleged delays and excess caution in exercising its resolution and supervisory functions, the ruling party initiated legislative changes which reduced the central bank's resolution powers, eroded its independence and undermined its decision-making ability. Specifically, amendments to resolution legislation were voted in by parliament, which, in effect, transferred resolution powers from the central bank to the government; these changes enabled the government to exercise control over the new 'mega' bank created through the merger of 'good' Laiki and Bank of Cyprus.

Importantly, amendments were also made to central bank governance, which enabled the government to strengthen its control over the central bank by appointing two executive directors to its board without clear duties or reporting lines. These amendments were effected in late summer 2013 notwithstanding a legal opinion published by the ECB which warned of the negative consequences for central bank independence and its decision making processes. Specifically, the opinion states the following:

"Although the draft law purports to vest two members of the Board with executive powers, in addition to the Governor, it does not specify the corporate governance arrangements applicable to the CBC once the draft law has entered into force. In the ECB's view, the draft law should provide clarity in terms of: (a) the precise scope of the powers and tasks to be assigned to the executive directors, (b) the limits of the competence of the executive directors when assisting the Governor, in particular as regards whether the executive directors will have decision-making powers and (c) the position of the proposed executive directors in the CBC's organisational structure, for instance, whether or not CBC staff members will report directly to the executive directors. In particular, the independence of the Governor of the CBC should be reinforced by ensuring that the assistance provided by the executive directors to the Governor should be conducted under the supervision of the Governor. Without clarity in these

\footnotetext{
39 It should also be noted that the Cypriot church owns one of the television channels and exerts influence, if not control, over at least one major 'independent' newspaper.

40 See, for example, J. Black "Cyprus Central Bank Independence Attacked”, Bloomberg, 13 April 2013.

41 The president annulled the appointment of the deputy governor through an Act of Government, claiming that the original appointment was unconstitutional. Although the central bank initially challenged the action in the Supreme Court, it was eventually forced to withdraw the case when a new board of directors was appointed by the government.
} 
respects, the ECB is concerned that the CBC's decision-making processes will be undermined." 42

In addition to legislative changes that eroded the independence of the central bank and undermined its decision making processes, very much as predicted by the ECB's legal opinion, the government and parliament launched several investigations into the banking collapse which, initially at least, were aimed at the central bank's role in managing the crisis, while downplaying the role played by bankers and neglecting the responsibilities of parliament, the Cypriot 'business model' and the wider political system. Throughout 2013, the government continued to criticize the central bank governor for alleged delays in supervisory or resolution actions and publicly threatened his dismissal. ${ }^{43}$

On 10 March 2014, the central bank governor submitted his resignation alluding to difficulties working with the central bank's board and personal circumstances. The Economist described the event as "A blow to central bank independence". ${ }^{44}$

It is noteworthy that within six months of appointing a new governor to the central bank, political parties, including the ruling party, were demanding her resignation over alleged irregularities relating to her contract. Soon after that, the president declared that he would initiate the process of her dismissal. To date, however, such a process has not been initiated. More recently, there have been new allegations about the new governor's role in her previous post as auditor general - which had previously been widely considered successful. Although information remains vague, press reports are indicating that a new criminal investigation has been launched to examine allegations that she may have misled parliament in relation to the procedures followed for the purchase of helicopters by the previous government. Although it is impossible to ascertain whether such allegations are valid, there is little doubt that protracted police investigations that target the central bank and its governor can generate a climate of intimidation that weakens the independence of the central bank and further erodes its ability to stand up to political pressure.

\footnotetext{
42 Opinion of the European Central Bank of 5 June 2013 on changes to the governance of the Central Bank of Cyprus. https://www.ecb.europa.eu/ecb/legal/pdf/en_con_2013_41_f_sign.pdf

43 Additional pressure was exerted through public death threats to the governor and his family, see, for example, J. Black "How Trading Blame Led to Death Threats for ECB's Gypriot Banker", Bloomberg, 29 May 2013. http://www.bloomberg.com/news/articles/2013-05-29/how-trading-blame-led-to-death-threats-for-ecb-scypriot-banker

44 "The departure of Cyprus's central-bank governor: a blow to central bank independence", The Economist, 10 March 2014.
} 


\section{Concluding remarks}

Stripped to its basics, the Cypriot crisis is very much a tale of two banks becoming too big to fail, too big to save and too big to regulate. The banking system doubled in size within five years of Cyprus joining the EU thanks, largely, to unfettered capital inflows that reflected growing business and political links between Russia and Cyprus. The banks took full advantage of the culture of lax corporate governance and inadequate accountability, which furthered the interests of politically connected law firms, banks and professional services firms that made up the 'Cyprus business model'. Media and political capture meant that the growing contingent liability that the banks represented for the public finances remained unnoticed until it was too late.

The final bill for rescuing the banking system was too large for a small country to pay. Moreover, it arrived at the time when European policy makers were experiencing fatigue with bank bailouts and were looking for more tax efficient methods of rescuing banks. The solution for Cyprus that Europe and the IMF came up with involved bailing in shareholders, bond holders and uninsured depositors, which protected the public finances, and in so doing spared the Cypriot taxpayer and future generations from a much higher bill. By sparing those who could least afford it, it also minimised the impact on the real economy and expedited the recovery, which is now well under way. However, by shifting the burden to the wealthiest and most politically connected sections of society, it created toxic fallout that eroded the independence of institution that took all the upfront resolution actions and brought the justice system under unprecedented political pressure. If institutions such as central bank independence and the rule of law are indeed the cornerstone of low inflation and sustained long-term growth - if not democracy itself - the longer-term consequences of the Cypriot 'solution' may well outweigh any short or medium-term benefits.

\section{References}

Andrianova, S., P. Demetriades and A. Shortland (2012) "Government Onwership of Banks, Institutions and Economic Growth", Economica, Vol 79, 449-469.

Arcand, J., E. Berkes and U. Panizza (2015) “Too Much Finance?”, Journal of Economic Growth, Vol. 20(2), 105-148.

Balazs, E., (2016) “Cyprus Turns Economy Around, Successfully Exits IMF Program”, IMF Survey, March 15, 2016. 
Central Bank of Cyprus (2013a) "Introductory Statement by Panicos Demetriades, Governor of the Central Bank of Cyprus before the Investigation Committee on the Economy" (13 August).

Central Bank of Cyprus (2013b) "Rescue Programme for Laiki Bank", 30 March 2013.

Deakin, S. (2016), "The role of law in economic development: the case of Russia", mimeo, University of Cambridge.

Demetriades, P. (2012) "Cyprus financial crisis: the framework for an economic recovery within the Eurozone", Speech by Panicos Demetriades, Governor of the Central Bank of Cyprus at a discussion organized by the Hellenic American Bankers Association and the Cyprus-US Chamber of Commerce, New York 11 December 2012.

Demetriades, P.O. and K.A. Hussein (1996) "Does Financial Development Cause Economic Growth? Time-series evidence from 16 countries", Journal of Development Economics, Vol 51(2), 387-411.

Demetriades, P.O. and P.L. Rousseau (2015) "The Changing Face of Financial Development”, Economics Letters, Vol. 141, 87-90.

Laeven, L., and F. Valencia (2013) "Systemic Banking Crises Database", IMF Economic Review, Vol. 61, 225-270.

Lascelles, D., Green, D., G. Charalambous and P. De Weck (2013) "Independent Commission on the Future of the Cyprus Banking Sector: Final Report", 31 October 2013.

Minsky, H.P., (1992) “The Financial Instability Hypothesis”, Levy Economics Institute of Bard College, Working Paper No. 74 (May).

Stephanou, C. (2011a) "Big Banks in Small Countries: The Case of Cyprus", Cyprus Economic Policy Review, Vol 5 (1).

Stephanou, C. (2011b) “The Banking System in Cyprus: Time to Rethink the Business Model?" Cyprus Economic Policy Review, Vol. 5 (2), 123-30.

Zettelmeyer, J., C. Trebesch and M. Gulati (2013) "The Greek Debt Restructuring: An Autopsy", Economic Policy, July, 515-563. 